\title{
Review of the reproductive physiology of the scallop, Pecten maximus, applicable to intensive aquaculture
}

\author{
Nicolc Devauchelle and Christian Mingant \\ IFREMIR, Cenlre de Brest, BP 7o, 29280 Plouzané, France.
}

Reccived July 11, 1990; acceptcd November 22, 1990.

Devauchelle N., C. Mingant. Aquat. Living Resour., 1991, 4, 41-51.

\begin{abstract}
This paper presents a summary of information on reproduction biology in the scallop, Pecten maximus, which is required for the successful reseeding and intensive aquaculture programs developed in France since 1982. Data are presented on the following subjects: environmental factors that sustain gametogenic activity and the timc of year this activity occurs; biochemical changes that are associated with gametogenesis; the consistency of egg quality; and development of a simple test to predict egg quality.
\end{abstract}

Keywords : Aquaculture, Pecten maximus, scallop, hatchery, reproductive physiology, egg quality, embryo, gametc.

La physiologie de la reproduction de la coquille Saint-Jacques, Pccten maximus, appliquée en aquaculture intensive.

Résumé Cet article présente un résumé des connaissances sur la reproduction de Pecten maximus, étape-clé du succès des programmes de repcuplement et d'aquaculturc intensive lancés en France dès 1982. Des données synthétiques renvoient à une bibliographie de base et répondent à des questions aussi variées que: quels facteurs influent sur la gamétogenèsc? A quel moment de l'année? Quclles sont les modifications de la composition biochimique de Pecten maximus enregistrées au cours de la gamétogenèse? Les gamètes produits sont-ils de qualité constante? Enfin dispose-t-on de tests simples et fiables pour cvaluer cette qualité?

Mots-clés : Aquaculture, Pecten maximus, ćcloserie, physiologie de la reproduction, embryon, gamète.

\section{INTRODUCTION}

Natural production of juvenile scallops, Pecten maximus, collapsed along the Atlantic coast of France in the mid 1970s. As a result, the rebuilding of scallop fisheries and development of aquaculture activities depended, at least initially, on the artificial or hatchery production of juveniles (Boucher and Dao, 1989).
The first attempts at artificial reproduction in Pecten maximus were done by Comely (1972). Since then a large number of spawnings have been undertaken using the following technique: mature scallops dredged from the open sea are acclimated for a few days in tanks and then submitted to short $(20 \mathrm{~min})$ fluctuations of thermal stimulation $\left(5-7^{\circ} \mathrm{C}\right.$ ) (Cochard and Gérard, 1987); after the gametes are released they are placed in tanks with seawater at $15^{\circ} \mathrm{C}$ and large amounts of microalgae are added. This technique has 


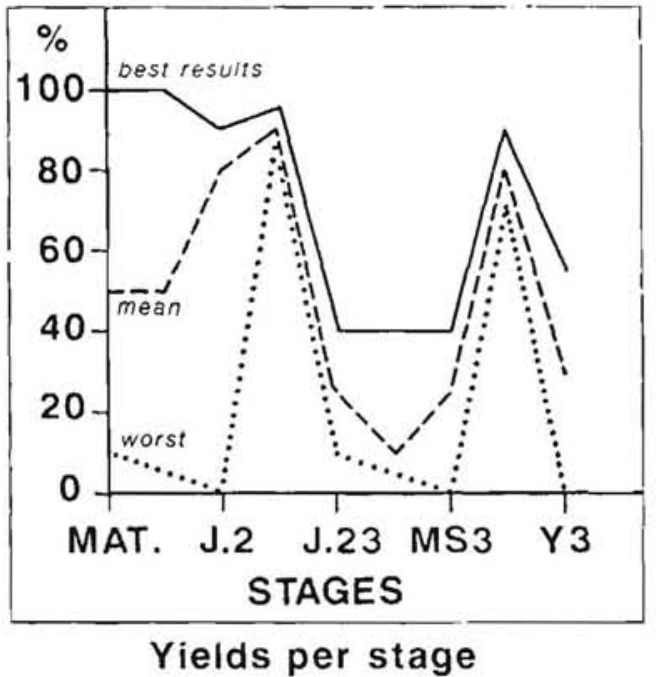

Figure 1. - Summary of the average survival $(\%)$ of Pecten maximus recorded at different stages in their life cycle from mature adults (MAT) to a crop of 3-years-old (Y3). The middle values are usually obtained during spring and summer. J2, larvac at two days old; J23, larvae at 23 days old (i.e. metamorphosis); MS3, scallops three months old.

been used to produce juvenile scallops which are then grown to commercial size (Buestel et al., 1987). It was evident that improvements had to be made in all phases of the artificial propagation of juvenile scallops if economically viable commercial production

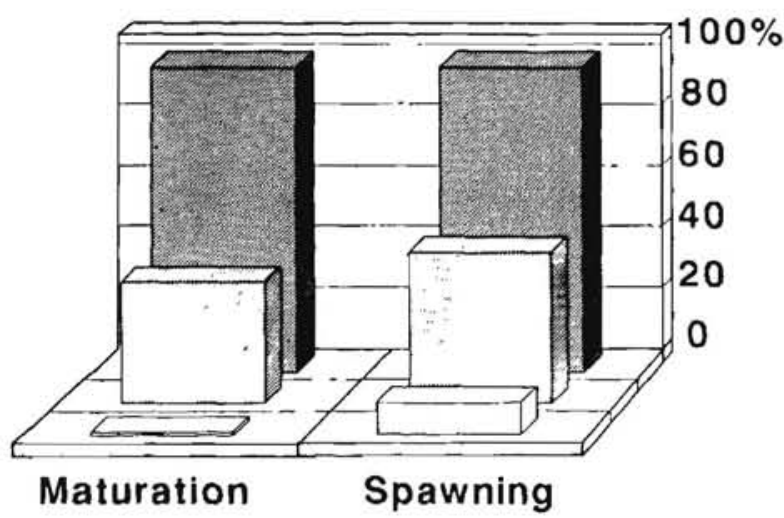

Figure 2. - Mean efficiency (\%) of techniques used to condition Pecten maximus to become scxually mature and for stimulating gamete release. Poorest results arc obtained in autumn and winter, middle results in spring and summer, the best results are irregular and obtained at the very biginning of summer.

was to be achieved (figs. 1 and 2). The high variation in spawning success in hatcheries had to be reduced and the relationship between condition of broodstock and survival and growth of larvae needed to be established.
Data collected over a period of four years provided information on the reproductive physiology in natural populations of scallops (Boucher and Dao, 1989). Further, experiments were conducted in hatcheries to determine the effect of environmental factors that were believed to be important to stimulate gametogenesis.

This paper reviews information in the field of reproductive biology of the scallop, Pecten maximus. The first part reviews information in the literature on the reproductive biology in scallops. The second part presents results of experimental work carried out by IFREMER. The need for further research work in this ficld is discussed.

\section{BASIC DATA ON THE NATURAL, REPRODUCTIVE CYCLE}

\section{Biology}

Pecten maximus is a functional hermaphrodite, both male and female reproductive organs are present in the gonad. Gametogenic activity begins during the second year. The reproductive cycle is shown in figure 3. Several months are required to attain sexual maturity. At this time the gonad contains the orange-red ovary and the creamy-white testis. Stages in gonadal development are described according to the criteria of Mason (1958) and previously described by Cochard and Devauchelle (1991).

- Stage 1: The gonad is poorly differentiated into ovary and testis. The ovary is uniformly translucent and brown coloured. The male part may be slightly whitish with very few visible follicles.

- Stage 2: The gonad is clearly differentiated into white testis and orange ovary: the follicles are still small and sparse. The entire loop of the alimentary canal is visible in the gonad.

- Stage 3: The follicles are larger and denser but space remains between them. The alimentary canal is difficult to see but causes the wall of the gonad to bulge.

- Stage 4: The gonad is flabby but the follicles are packed together. The alimentary canal causes the wall of the gonad to bulge but is seen only at the distal part of the loop.

- Stage 5: The gonad is firm and rounded to the tip. The follicles are closely packed together and the alimentary canal is nearly indistinguishable.

Development of the gonad until the oocyte stage (before final maturation) requires about two months. There are always several oocyte stages in the gonad during gametogenesis.

The time of spawning can vary slightly from area to area. Along the French coast the main spawning periods are in June and September although it may be as early as April/May after mild winters. However, 


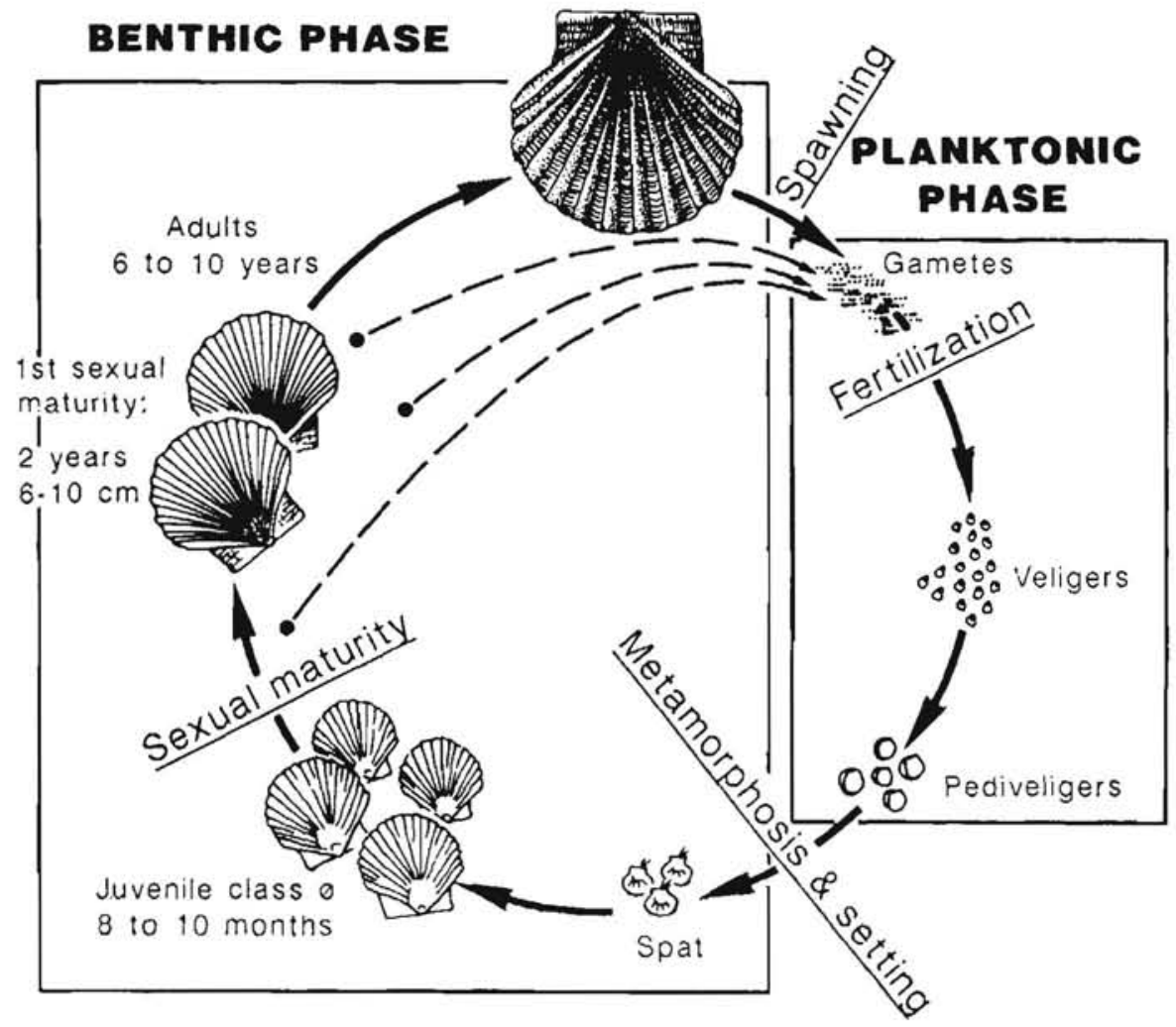

Figure 3. - Life cycle of the scallop, Pecten maximus.

gametogenic activity can vary greatly from area to area. There is continuous gametogenic activity in scallops in all areas except in the Bay of Saint-Brieuc (fig. 4). This is shown by seasonal variation in levels of $R G H^{3}$ (Gonad wet weight/shell height ${ }^{3}$ ). 100 in the gonad (fig. 5). Seasonal variations in biochemical levels in the gonad are also characteristic of gametogenic data. A complete rest in gametogenic activity was seen from histological examination of scallops from Saint-Brieuc while in other populations the gonads always contain oocytes.

\section{Biochemical cycles in gametogenesis}

Variations in glycogen content of the muscle are linked with variations of $R G H$ in the gonad. According to Lubet et al. (1987) glycogen is transferred from the muscle to the gonad at the end of the gametogenic cycle. Seasonal values are similar among different populations and range between 2 and $22 \%$ of the muscle (dry weight).

The scallop muscle is also characterized by seasonal variations in water content, figure 5 shows two types of variation:

- seasonal variations which are of greater amplitude $(72.5$ to $77.5 \%)$; the minimum value is observed at the end of spring, the maximum during winter time;

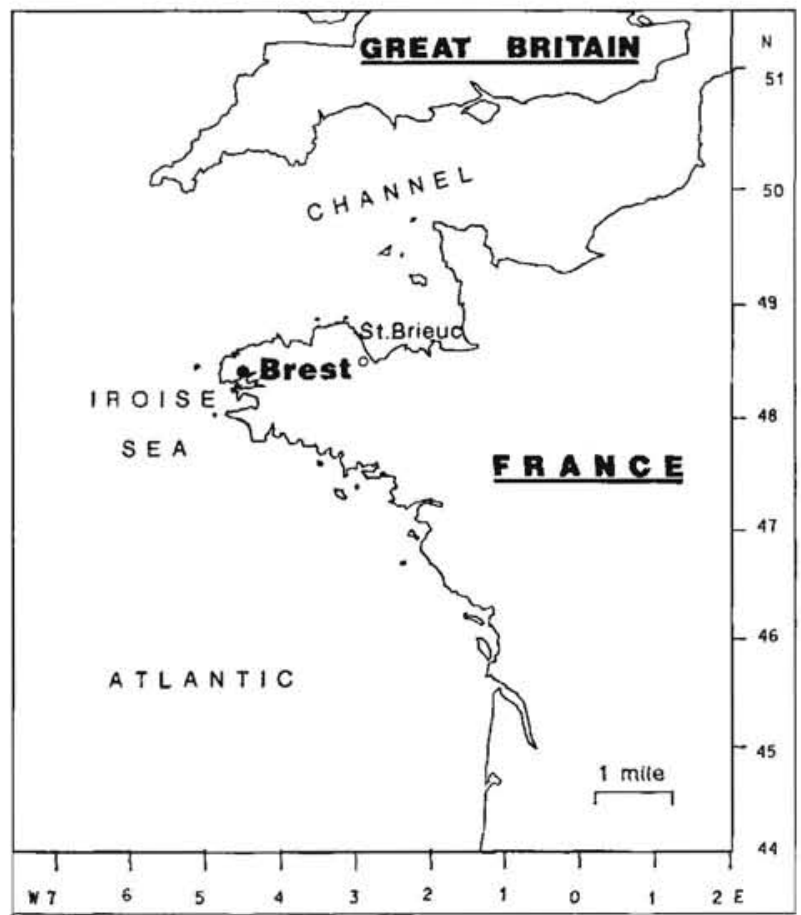

Figure 4. - Situation of the French areas of origin of the scallops. 


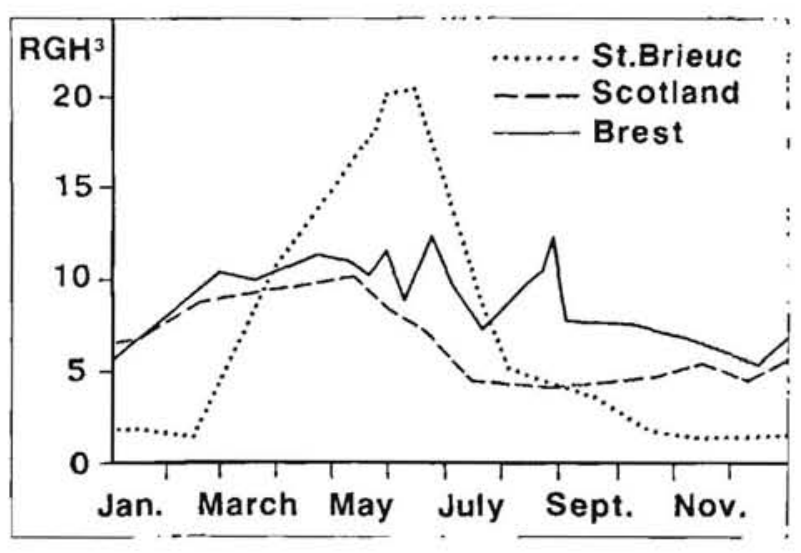

Figure 5. - Compared $\mathrm{RGH}^{3}$ (Gonad wet weight/(shell height $)^{3} \times 100$ ) of Pecten maximus from Saint-Brieuc Bay (Channel) and Bay of Brest (Atlantic), France and from the Isle of Skye, Scotland. The data were collected in 1987. Gonad wet weight (g), shell height $(\mathrm{cm})$.

- variations linked with spawning activity which are of lesser importance; minimum values are observed before spawning, maximum values after spawning.

Variations in dry matter give the best correlation with gametogenic activity in the gross biochemical composition of male and female gonads (fig. 6). Variations are generally similar to those of the muscle, i.e. low values before spawning and higher values after spawning. Maximum variations are linked to spawning activity and are $4 \%$. As observed with the muscle, seasonal variations are observed in the gonad. In autumn and winter the gonad of the Saint-Brieuc population contained only $18 \%$ dry matter during the sexual resting stage while in other populations with continuous gametogenic activity the accumulated dry matter during winter had a mean of $23.5 \%$. This also indicates that in winter the gonads are still in the vitellogenesis stage even though the gametes are not released, probably because of low water temperatures.

\section{Nervous system and hormonal controls}

It is believed that gonadal development in bivalves is controlled by the nervous system (fig. 7) (Lubet and Streiff, 1982), probably by thermal and light stimulation as has been observed in other marine poikilotherms particularly crustaceans and fish (figs. 8 and 9). Because the cyes in scallops have a cornea, a crystalline and two retinas (one inverse and one direct), light is probably important in the reproductive cycle. Nutrition is also probably important, but its role in bivalves, particularly in scallops, is virtually unknown. The isolation of peptidic hormones from nervous ganglia indicates their importance in gonadal development. Matthieu (pers. comm.) has extracted a somatostatine-like hormone from the cerebroid ganglia which would act positively on vitellogenesis; oocyte maturation and mitosis as has been observed in Mytilus edulis (Matthieu et al., 1988).

\section{THE ARTIFICIAL CONTROL OF GAMETE PRO- DUCTION}

The main objective in bivalve hatcheries is to obtain large quantities of high quality eggs at any time of the year to enable commercial hatcheries to continue production of juveniles over a long period of time and to provide material for research laboratories ( fig. 10). Reliable techniques must be developed to extend the spawning period of scallops but still preserve fecundity and egg quality. Experimental studies were carried out on 3-ycar-old scallops to investigate the effect of external factors on the gonadal cycle and other characteristics of different scallop populations. The experimental holding units are shown in figure 11 . Scallops were placed on sand substrate and fed microalgae: Isochrysis galhana (clone tahitien), Chaetoceros calcitrans and Pavlova lutheri.

The food ratio ranged from $8 \times 10^{9}$ to $15 \times 10^{9} \mathrm{per}$ scallop per day depending on the system used for water rencwal. When the gonads reached stages 4-5 (see above) the scallops were subjected to 1-3 thermal stimulations. Released oocytes werc separated from homologue sperm and then cross-fertilized with sperm from another animal at a maximum ratio of 10 spermatozoa for 1 oocyte. Two to four hours after fertilization, the number of normally developed embryos was counted. In some experiments the eggs were incubated by placing them in beakers at a maximum density of 100 per $\mathrm{ml}$ for two days after which the number of normal larvae was counted. In order to study the relationship between conditioning of adults and the subsequent performance of larvae, some larvae were reared to maturity. Two-day-old larvac were placed in 2 liter beakers (5 per $\mathrm{ml})$. Growth and survival was recorded at day 9,16 and 23 as described in Cochard and Devauchelle (1991).

\section{Effect of internal factors}

Internal factors include individual characteristics such as age, morphology, growth rate before gonadal development, health and origin of the individuals. Another factor that could be important is the reproductive strategy of local populations.

Cochard and Devauchelle (1991) studied gametogenic activity in five geographically separated populations of scallops from November to February when differences in gametogenic activity would be most divergent. The results showed that during this period seasonal gametogenic activity of the Saint-Brieuc population was different from the other four populations (fig. 12). This was attributed to a difference in genetic characteristics of this stock. Differences in 
seasonal spawning

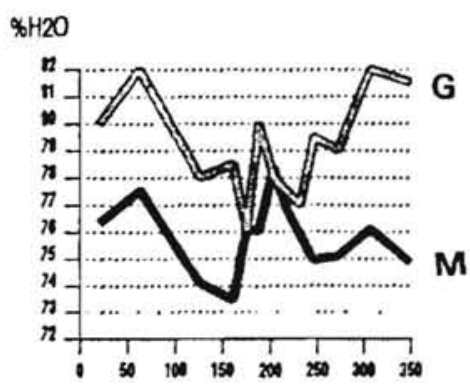

कGLIY

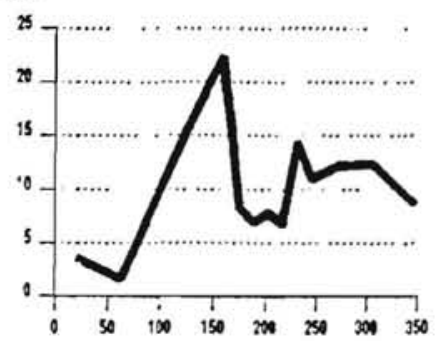

IG

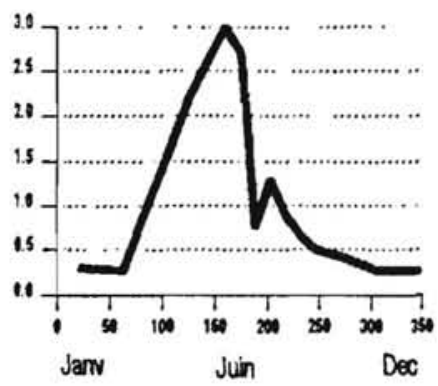

\section{non seasonal spawning}

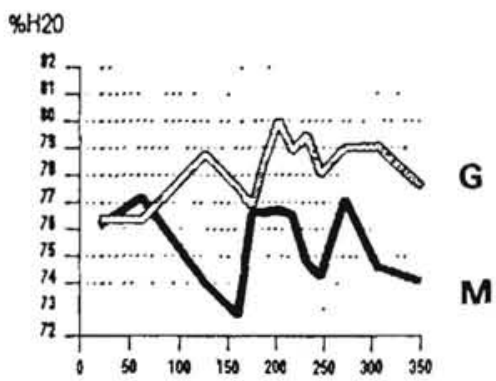

\%GLYY

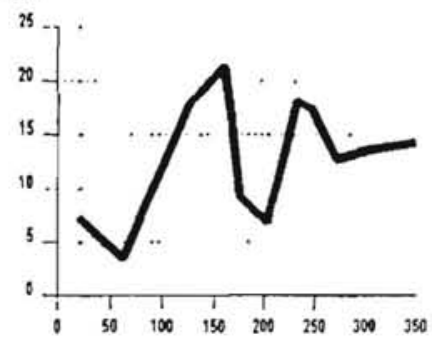

IG

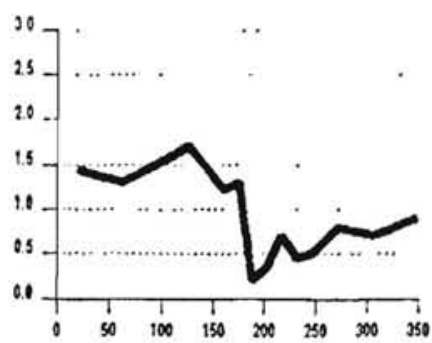

Figure 6. - Functions in the biochemistry of the gonad $(\mathrm{G})$ and adductor muscle $(\mathrm{M})$ in Pecten maximus $-\% \mathrm{H}_{2} \mathrm{O}$, water content; $\% \mathrm{GLY}$, content of glycogen in the adductor muscle $(\%$ dry weight). IG, gonadal index $=\mathrm{RGH}^{3} \times 10$.

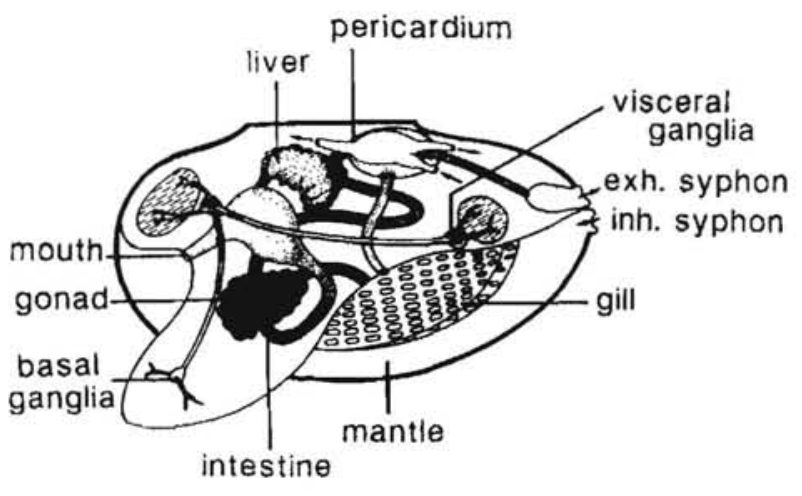

Figure 7. - Organization of the nervous system in most bivalves. fecundity were found among the other four populations which were attributed to variations in the state of the animal when conditioning began.

Photoperiod also affects gametogenic activity (fig.13). Again differences were noted between the Sant-Brieuc and Brest populations, as the latter population responded to a greater extent to photoperiod. This agrees with results of Couturier (in press) with Placopecten magellanicus. Along the Brittany coast the effect of food seems to be as dominant as photoperiod in stimulating gametogenesis in the Brest population where the gonad is full all year round and there are no obvious differences in developmental stages.

Nutritional studies showed a difference in gametogenic activity between various populations (fig. 14). Gonads of the Saint-Brieuc population responded 


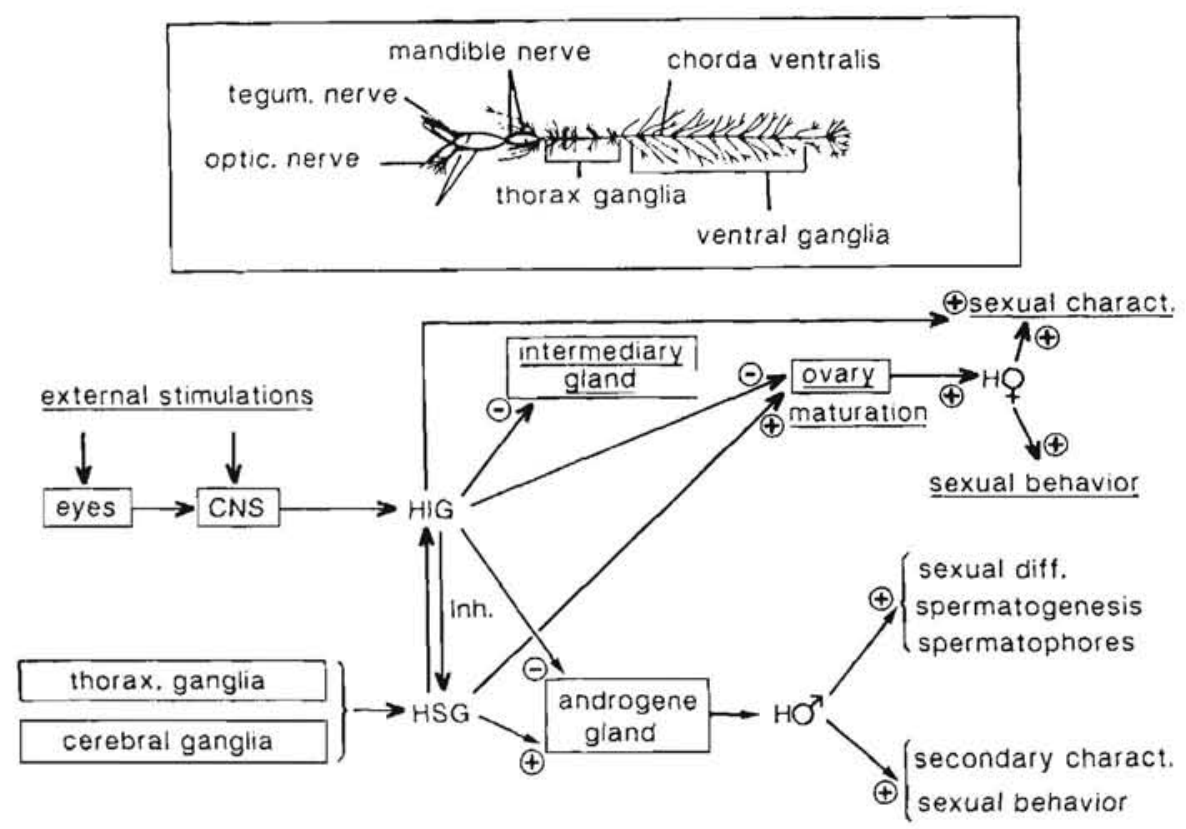

Figure 8. - Schematic diagram of the neurohormonal control in crustaceans.

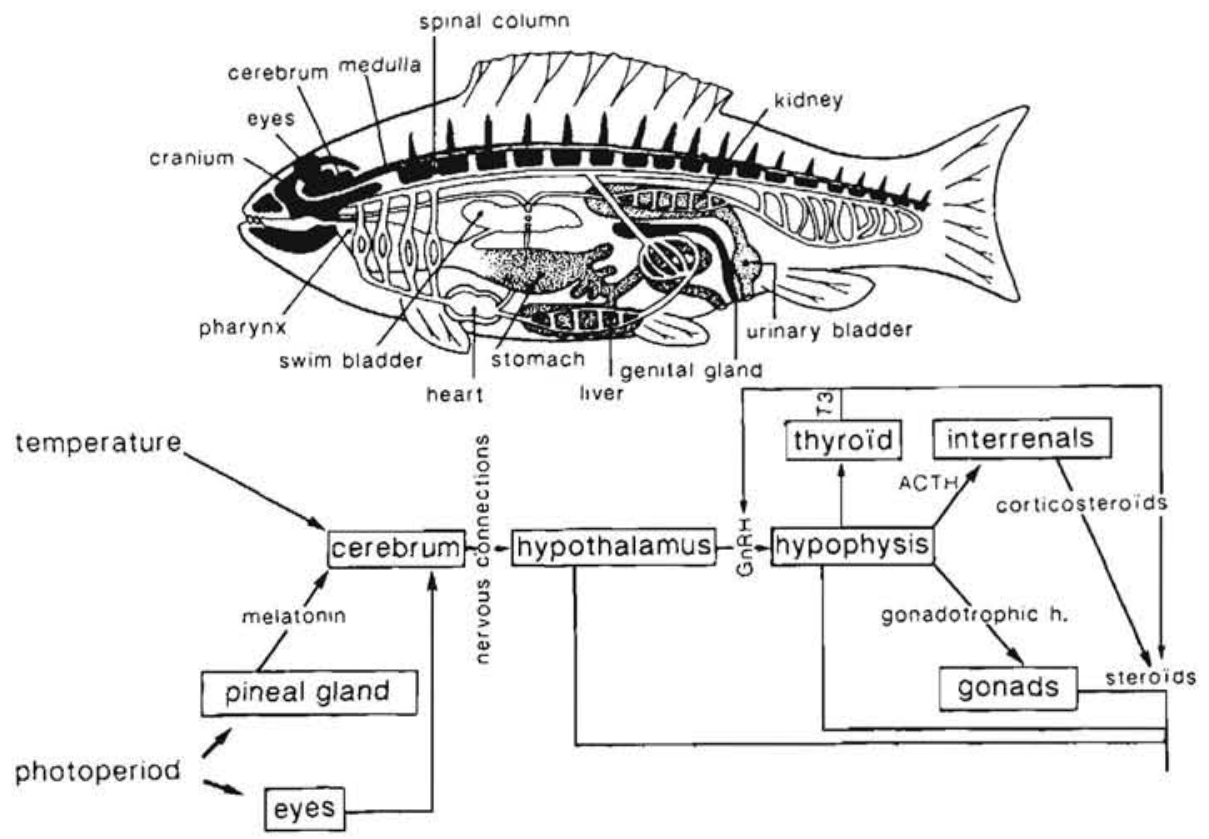

Figure 9. - Schematic diagram of the neurohormonal control in fish.

more slowly to high levels of food than the Brest population. Observations of the muscle and gonad showed that under the same rearing conditions the Brest population muscle contained more dry matter, up to $27 \%$, than the Saint-Brieuc population (maximum $20 \%$ ). The Saint-Brieuc population would have less muscle reserves to transfer to the gonad than the
Brest population which has a more elastic muscle in terms of size, weight and dry matter.

No difference was observed in oocyte diameter in spawned eggs between any population. Also, no difference was observed in larval performance (survival and growth rate) between any of the populations. 


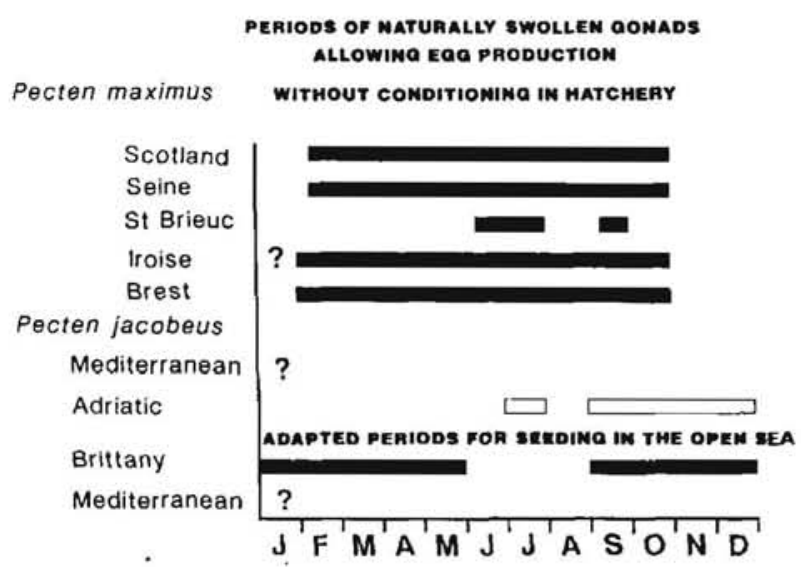

Figure 10. - Diagram of periods when gonads of Pecten maximus from various locations are ripe and might produce eggs. Also shown are the optimum periods for seeding juveniles in the open environment.

In conclusion it is clear that in hatchery operations, differences in gonadal cycles and conditioning of different populations must be considered. The reason for these differences between populations (genetic or phenotypic) remains unknown.

\section{Effect of external factors}

Four main external factors may influence spawning success of bivalves:

- physical-chemical characteristics of seawater: temperature, salinity, $\mathrm{pH}$, turbidity, and mineral content;

- light, both solar and lunar;

- rearing techniques used during gametogenesis, incubation period and the spawning techniques;

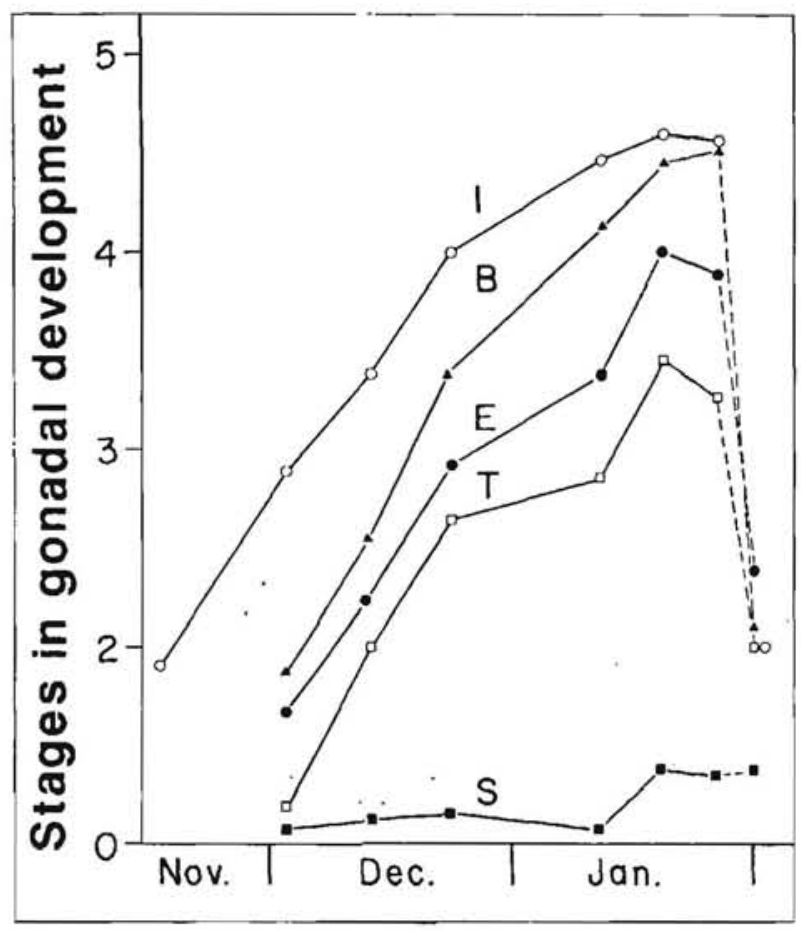

Figure 12. - Comparative development of the gonadal stages in Pecten maximus during conditioning that originated from Bay of Brest (B), Iroisc sca (I), Saint-Brieuc Bay (S) and spat transferred to Saint-Brieuc Bay from Scotland (T) (after Cochard and Devauchelle, 1991).

- food, quantity and quality, including phytoplankton and organic matter.

Until now the relative importance of each factor has not been clearly defined (Devauchelle, 1989). Previously the timing of bivalve gametogenesis was presumed to be related to nutrition, temperature and photoperiod.

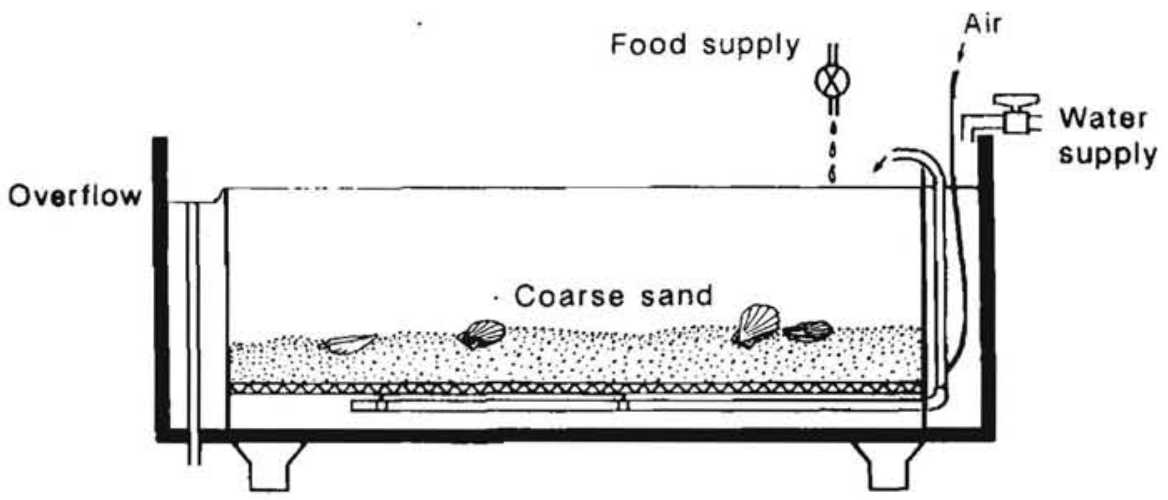

Figure 11. - Diagram of experimental tanks used for conditioning scallops. Regardless of tank size $(2 \times 0.5 \times 0.5 \mathrm{~m}$ or $1.2 \times 0.8 \times 0.8 \mathrm{~m})$ the substrate was always sand and each tank was fitted with an airlift pump. 


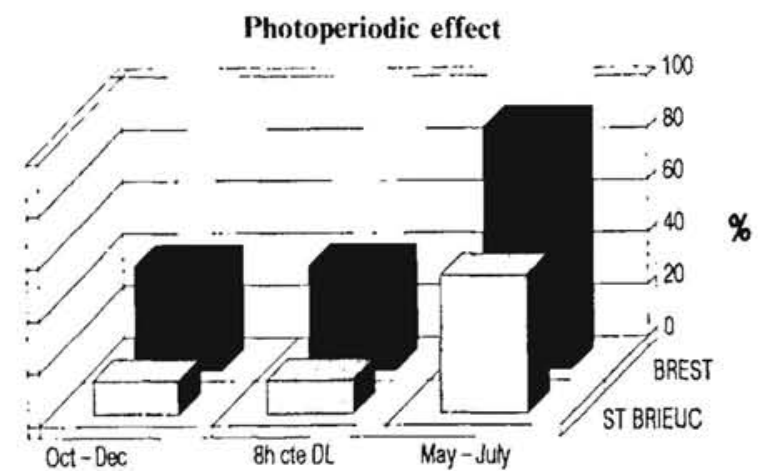

Figure 13. - Relationship between spawning in Pecten maximus $(\%)$ and three photopcriods: short and constant, 8 hours of light per day $(8 \mathrm{~h})$; increasing light exposure from 15 to 15.15 hours per day (May-Junc); and decreasing light from 14 to 8.30 hours per day (October-Deccmber).

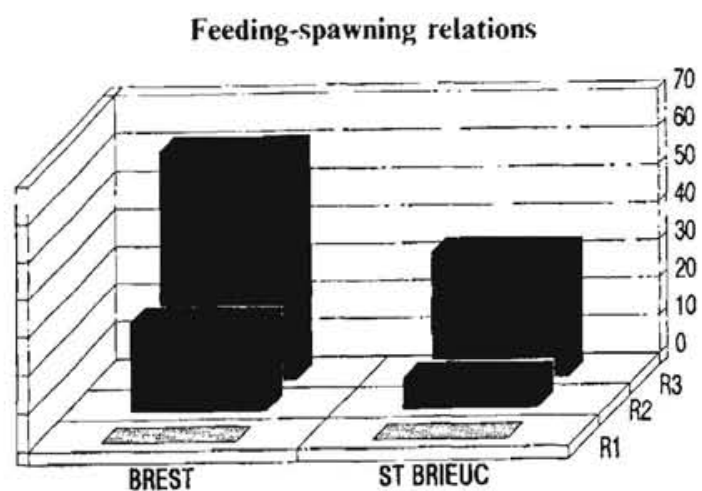

Figure 14. - Relationship between amount of food ( $R$ ) red Pecten maximus and spawning $(\%) . R 1=0, R 2=3.10^{\circ} \mathrm{cells} / \mathrm{animal} / \mathrm{day}$ and $R 3=14.10^{\circ}$ cells/animal/day and were stimulated to spawn after 28 and 45 days of conditioning.

\section{Temperature effect}

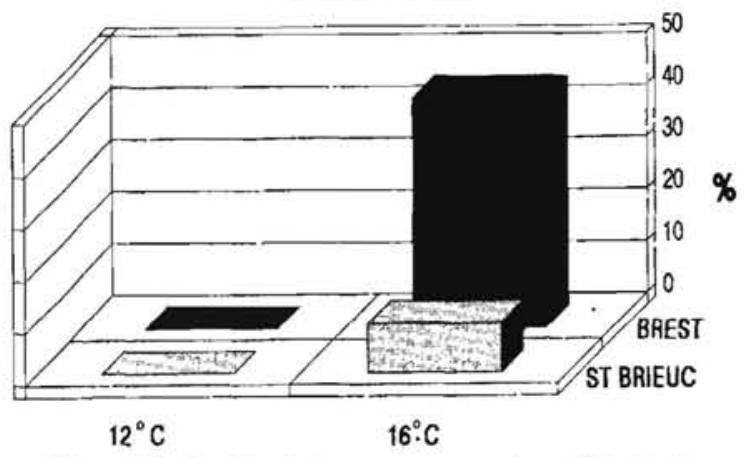

Figure 15. - Relationship between gametogenic activity in Pecten maximus $(\%)$ and temperature $\left({ }^{\circ} \mathrm{C}\right)$.

Results of recent work provide additional information on the subject. Duration of gametogenesis was shown to be linked to temperature and food levels (figs. 15 and 16). At similar gametogenic stages, fecundity is lower when food levels are lower. Gonadal activity suffers first at lower food levels but only in the female part of the gonad. When food levels are sufficient to maintain somatic activity then gonad activity proceeds at a high level. Water content of the gonad decreased as ovogenesis increased but there was no relationship with the intensity of spermatogenesis.

\section{Gametogenesis duration and nutrition}

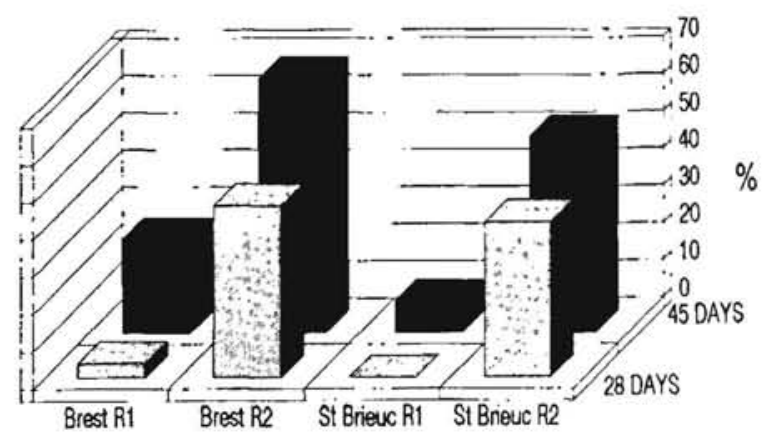

Figure 16. - Percentage Pecten maximus that originated from Brest and Saint-Brieuc Bays. The scallops were conditioned at two food levels $\left(\mathrm{R} 1=3.10^{9} \mathrm{cells} / \mathrm{animal} / \mathrm{day} ; \mathrm{R} 2=14.10^{9} \mathrm{cells} / \mathrm{animal} ;\right.$ day) and were stimulated to spawn after 28 and 45 days of conditioning.

The effect of light on the gametogenic cycle in scallops where the gonad is always full, Brest population, showed that increasing photoperiods accelerated gametogenesis compared to a short or constant photoperiod DL ( fig. 13) while in scallops with a resting stage, Saint-Brieuc population, gonadal mistosis was initiated. Decreasing photoperiods reduced gametogenic activity and egg production in all mature animals (figs. 13 and 17). This factor could be used to

Photoperiodic effect

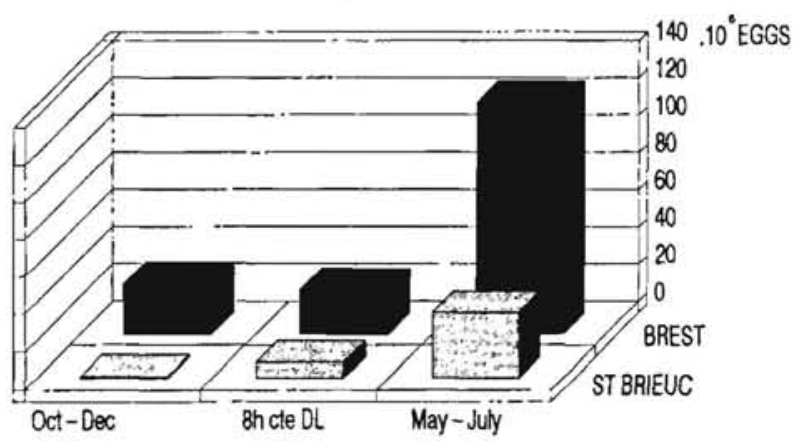

Figure 17. - Number of eggs spawned by Pecten maximus that originated from Brest and Saint-Brieuc Bays and reared under three different light regimes: short and constant $(8 \mathrm{DL})$; increasing from 15 to $18.30 \mathrm{DL}$; decreasing from 12 to $8.30 \mathrm{DL}$.

induce artificially a sexual resting period and gamete production at any time of the year as has been done with fish (Devauchelle, 1986). 
Table 1. - Summary of the effects of some internal and external factors on the reproductive activity of the scallop, Pecten maximus.

\begin{tabular}{|c|c|c|c|c|c|}
\hline \multirow[b]{3}{*}{ Parameters studied } & \multirow{3}{*}{$\begin{array}{l}\text { - Internal factors } \\
\text { Geographical origin } \\
\text { of the animals }\end{array}$} & \multicolumn{3}{|c|}{ External factors } & \multirow[b]{3}{*}{ Temperature } \\
\hline & & \multirow[b]{2}{*}{ Food ratio } & \multicolumn{2}{|c|}{ Photoperiod } & \\
\hline & & & Decrcasing & Increasing & \\
\hline Gametogenesis duration & yes & + & - & + & + \\
\hline Fecundity & yes & + & - & $+^{*}$ & $\begin{array}{c}\text { Syncrgic effect } \\
\text { with the food } \\
\text { ratio }\end{array}$ \\
\hline Survival/growth rates of larvae & ycs lightly & 0 & & & \\
\hline
\end{tabular}

+ , Proportional effect; - inverse effect; 0, without cffect. ( ${ }^{*}$ only for Saint-Brieuc strain).

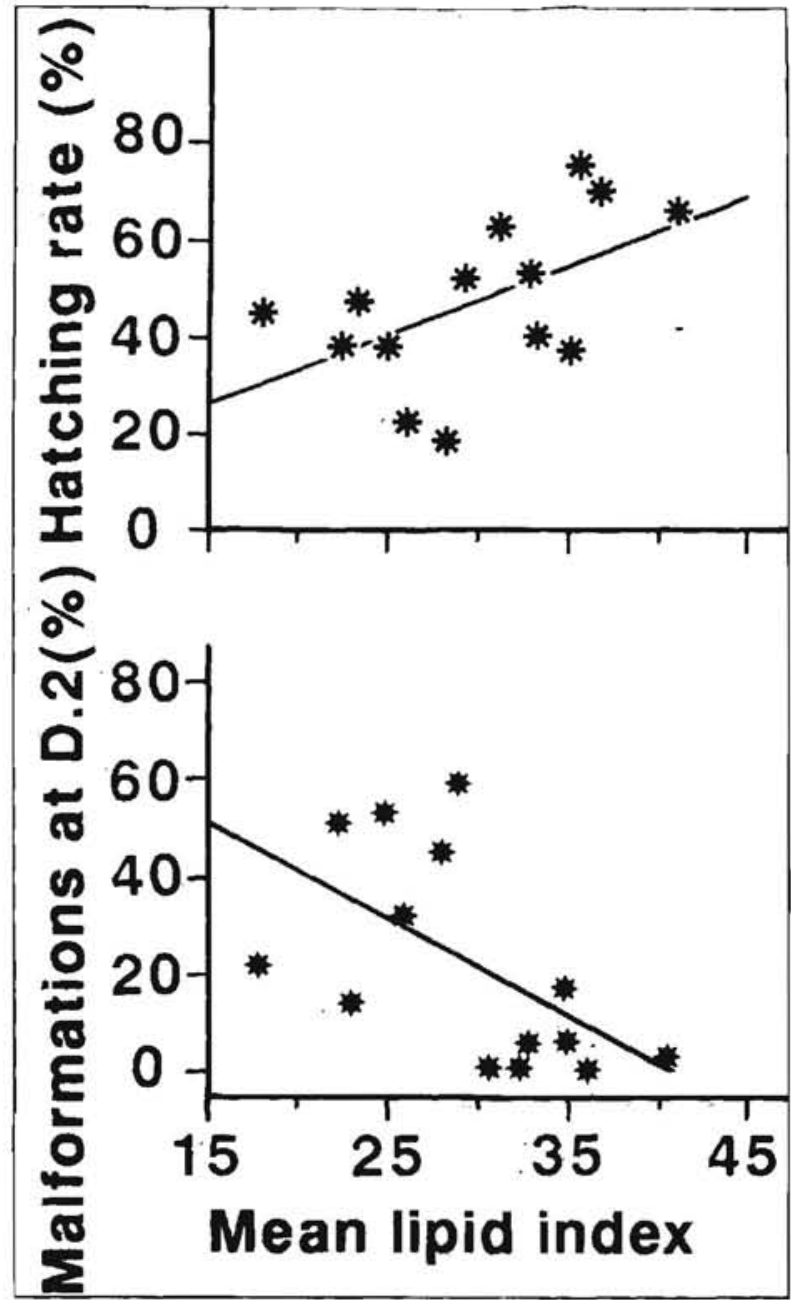

Figure 18. - Relationship between amount of lipid reserves in oocytes and the production of abnormal larvae and survival of larvae of Pecten maximus at days two (from Dorange et al., 1989).

The effect of light on the induction of spawning is unknown.

In all experiments, variations in dry matter in muscle and gonads were synchronous which has also been observed in natural populations. When a group of scallops was used in successive experiments without a resting period, the fecundity was greatly reduced. At the same time a very high water content, up to $80 \%$, indicated that reserves were very low in the muscle and that gametogenesis activity was low. Actual levels of water content in the gonad ranged between 76 and $82 \%$ and levels in muscles from 72 to $78 \%$ during the gametogenic cycle. Table 1 summarizes the relationship that was established experimentally. The ratio of food to suspended particles appeared to be important in order to obtain high fecundities although it has not been proved as is the case in Ruditapes philippinarum (Devauchelle, unpubl.) and Ostrea edulis (Stephenson and Hclm, 1971). However, as Utting (pers. comm.) showed for both these species, dissolved and suspended organic material could be as important as the algal supply.

\section{Relationship between conditioning and larval rearing}

The effects of conditioning adults as well as spawning techniques on production of larvae were observed only on 2-day-old larvae. From day 2 until metamorphosis no relationship was found between any factor tested and development. At metamorphosis a relationship was found between the origin of the scallop broodstock and the yield of mature larvae (Cochard and Devauchelle, 1991).

\section{Criteria for egg quality}

The term egg quality as used here means the percentage of fertilized oocytes that developed to the 2day-old larval stage (D larvae) and continued to have high growth and survival rates until they were metamorphosed (30-day-old larvae). Kjorvisk et al. (1989) and Devauchelle (1989) summarized information on different parameters that effect the rearing of fish and bivalve molluscs. Egg parameters that have been evaluated are physical measurements (diameter, weight), biochemical parameters (gross biochemical composition), and morphological data. (abnormalities, chorion structures and permeability). Various attempts were made to estimate these parameters on scallop eggs. 
Observations on oocyte maturity and measurements of egg diameter were made with a light microscope. No clear correlations were observed between egg diameter and survival rates (Devauchelle and Cochard, unpublish.). Observations with the electron microscope showed correlations between oocyte maturity and production of two-day-old larvae (Dorange et al., 1989).

Estimates of lipid content of oocytes and eggs showed a relationship between the frequency of lipid droplets, estimated by automatic scanning analysis, and the production of two-day-old larvae (fig. 18) (Dorange et al., 1989). A relationship was also demonstrated between fatty acid composition and food quality in the composition of eggs and larvae (Delaunay pers. comm.).

Egg density as calculated by techniques of cell separation centrifugation or isopycnic gradients of percoll also allowed for the prediction of survival of two-day-old larvae and growth rate or survival of mature larvae. Higher performance would be obtained with higher densities of eggs (1.040) (Faure, pers. comm.).

In summary, there are clear relationships between egg or oocyte characteristics and survival until twoday-old larvae. The simplest test for use in hatcheries would be estimation of density. Other physical characteristics of eggs should be investigated to determine correlations with production of two-day-old larvae including: refringence, first division synchronism, and membrane permeability to vital stains.

\section{CONCLUSION}

Research on scallop reproduction must be undertaken in order to improve the performance of hatcheries and also to understand the reasons for variations in reproductive behaviour in natural populations. To date efforts have focused on the maturation period, spawning techniques and the prediction of egg quality.
With respect to the maturation period, the relative importance of temperature, levels and quality of food and photoperiod must be thoroughly understood to provide standard conditioning practices for hatcheries. Since internal factors must also be understood, differences in behaviour of different strains must be investigated.

An improved method to determine maturity and what factor(s) initiate spawning is also necessary. The action of hormones should be studied in order to determine when gametogenesis is completed. Initially this requires a better understanding of hormonal control in bivalves.

Research on egg quality is also required. A peculiarity of bivalves is their dependence on food in the water where they live which contains both phytoplankton and dissolved organic matter. Differences in dissolved organic matter in different habitats may be very important and as a result the level of available food could vary from area to area. Hence it would be difficult to standardize a relationship between ingested food and egg quality in different natural populations. The existence of well established techniques to evaluate egg quality would be of great interest for hatcheries who want to rear batches of juveniles that have the best chance of survival. Development of an easy criterion could be useful to estimate the final quality of eggs at all hatcheries.

To understand the origin of variations in the reproductive capacity in natural populations, further investigations must be carried out in many fields, particularly in the field of toxicology.

Pecten maximus is not the only molluscan species of interest for aquaculture in France. Another species of scallop, Pecten jacobeus and the clam Ruditapes philippinarum are also reared in a similar manner. Similar information on reproductive strategies is required for these two species of bivalves. Initial investigations on the clam, $R$. philippinarum, showed that the importance of external factors on reproduction in that species was different to that in Pecten maximus.

\section{Acknowledgements}

Many thanks to Gilles Salaun who is in charge of the algal survey and to my bivalve colleagues, J. C. Cochard and J. C. Dao. I am grateful to Dr. Neil Bourne for his helpful comments and critical reading of the manuscript.

\section{REFERENCES}

Boucher J., J. C. Dao, 1989. Repeuplement et forçage du recrutement de la coquille Saint-Jacques (Pecten maximus). In: L'homme et les ressources halieutiques. Essai sur l'usage d'une ressource communc renouvelable, J. P. Troadec ed., IFREMER, 312-359.

Bucstel D., A. Gérard, J. C. Dao, 1987. Le programme de repeuplement en coquilles Saint-Jacques Pecten maximus en rade de Brest. La Pêche maritime, mars 1987, 164170. 
Cochard J. C., A. Gérard, 1937. Production artificielle de naissain de coquilles Saint-Jacques Pecten maximus (L.) en rade de Erest: analyse des facteurs affectant la croissance larvaire. In: The sixth International Pectinid Workshop, A. R. Eeaumont, J. Mason eds., Menai Bridge, Wales, 9-14 April 1987. ICES CM 1937/K:3.

Cochard J. C., N. Devauchelle, 1971. Spawning fecundity and larval growth in relation to controlled conditioning in five populations of Pecten maximus (L.). J. Exp. Mar. Exp. Eiol., 1:.

Comely C. A., 1972. Larval culture of the scallop Pecten maximus (L.). J. Cons. int. Explor. Mer., 3A, 365-378.

Couturier C., D. E. Aiken (in press). Possible role of photoperiod in sea scallop reproduction. C. R. Ass. Ann. Assoc. Agri., Ccongda, 3, 65-67.

Dzvauchelle N., 1935. Four marine fish in European hatcheries. Production contrôláe d'alevins en Europe. FAO Rep. Zadar/Pula, Youzoslavie, 10-28 February 1986, $50 \mathrm{p}$.

Devauchelle N., 1939. Eivalve molluscs reproduction in hatcheries. Haliotis, 12, 315-324.

Dorange G., Y. M. Paulet, M. Le Pennec, J. C. Cochard, 1989. Critères histologiques d'évaluation de la qualité des ovocytes émis par Pecten maximus (Mollusque, Bivalve). C. R. Acad. Sci. Paris, 309, 113-120.

Kjorsvik E., A. Mangor-Jensen, S. Holmefjord, 1989. Egg quality marine fishes. NY Fisk Rep., $n^{\circ}$ L.nr.5/89, The Norvegian College of Fishery Science, Univ. Tromsö, $29 \mathrm{p}$.

Lubet P. E., J. Y. Besnard, R. Faveris, S. Robbins, 1987. Physiologie de la reproduction de la coquille Saint-Jacques (Pecten maximus L.). Oceanis, 13, 265-290.

Lubet P. E., W. Streiff, 1982. Contrôle ncuroendocrine de la reproduction chez les mollusques. J. Physiol., Paris, $70,537-542$.

Mason J., 1958. The breeding of the scallop, Pecten maximus (L.) in Manx waters. J. Mar. Biol. Ass. UK, 37, 653-671.

Matthieu M., F. Lenoir, S. Robbins, 1988. A gonial mitosisstimulating factor in cerebral ganglia and hemolymph of the marine mussel Mytilus edulis L. Gen. Comp. Endocrirol., 72, 257-263.

Stephenson R. R., M. M. Helm, 1971. Supplementary algal feeding of a laboratory breeding stock of Ostrea edulis L. and its effect on a potential of larvac. ICES CM $1971 / \mathrm{K}: 28,11 \mathrm{p}$. 